\title{
FROM THE HISTORY OF BUKHARA FOLK MEDICINE
}

\author{
Behzod Kh. Hamdamov
}

Lecturer Bukhara State Medical Institute Bukhara, Uzbekistan

Shakhnoza V. Temirova

Doctoral Student Navoi State Pedagogical Institute, Uzbekistan

\section{ABSTRACT}

The most prominent representative of the doctors of Central Asia was Abu Ali Ibn-Sina (known in Europe as Avicenna), the largest doctor of the Middle Ages and one of the most prominent doctors in world history. He was born in 980 in the village of Afshana near the city of Bukhara. At the age of five, his parents transported him to Bukhara, where his studies began. From the teachers and from the books of the rich Bukhara library of the Samanids, Ibn-Sina received all the knowledge known by that time. However, Ibn Sina studied medicine deeper and most thoroughly. In his autobiography dictated by him, he said: "I took up the study of medicine, replenishing my reading with observations of patients, which taught me many methods of treatment that cannot be found in books."

KEYWORDS: - The Canon of Medicine, folk medicine, Pharmacy and pharmacology, Ibn Sina, history.

\section{INTRODUCTION}

At the beginning of the Middle Ages, the main agricultural population of Central Asia was made up of the ancestors of the peoples now inhabiting the Central Asian Soviet republics: Tajiks (Bactrians, Sogdians and related tribes and nationalities), Uzbeks, Turkmens, Kara-Kalpaks (Khorezmians and Turkic-speaking tribes and regions of the people living in and Bukhara). The culture of these peoples was distinguished by a high level. Long before the beginning of our era, the farmers of Central Asia learned how to draw canals for irrigating fields and created blooming fertile oases. The ancestors of the peoples of Central Asia built large cities with large buildings, surrounded cities with strong walls, and built dams. Various crafts were developed in the cities.

\section{THE MAIN RESULTS AND FINDINGS}

In the early Middle Ages, for several centuries, the peoples of Central Asia experienced the process of breaking the old slaveholding and patriarchalslaveholding relations and the formation of the feudal system. The class struggle in the era of early feudalism in Central Asia was intertwined with the 
CURRENT RESEARCH JOURNAL OF PHILOLOGICAL SCIENCES 2(12):

52-55, December 2021

DOI: https://doi.org/10.37547/philological-crjps-02-12-11

ISSN 2767-3758

(C)2021 Master Journals

Crossref do

81 Google

Accepted06 ${ }^{\text {th }}$ December, 2021 \& Published $11^{\text {th }}$ December, 2021

liberation struggle against the rule of foreigners Arabs who conquered Central Asia at the beginning of the 8th century. The conquerors - the Arabs brought the Muslim religion and the Arabian language to Central Asia. Central Asia in the 9th century economically grew so much that in the 10th century it was the most advanced region of the Middle East, at least economically, politically and culturally more progressive than the regions of Iran.

On the wave of the popular movement against Arab rule, the Samanid dynasty came to power in Central Asia, which by the 10th century became the rulers of one of the largest, richest and most cultured states of their time. This state managed to ensure the independence of Central Asia for a whole century in the fight against encroachments from Arab feudal lords and other external enemies.

The Samanid state had favorable conditions for the development of agriculture, crafts and trade. Ancient trade routes connected the Samanid state with China, India, Russia, the countries of the Caucasus and the Mediterranean. The dominance of religion, characteristic of feudalism, came to Central Asia later, from the end of the 11th century. Before that, the relative freedom of scientific consciousness, creative scientific thought in philosophy and natural science is still visible. Under the Samanids and subsequent dynasties in the 10th and 11th centuries, the culture of the peoples of Central Asia reached a high level of development. A number of economic, political and cultural centers had developed in Central Asia by the 9th-10th centuries. Central Asia was not only one of the most fertile and richest, but also one of the most cultured lands of the East. The capital of the Samanid state, Bukhara, and the capital of Khorezm, Urgench, were centers of science and art: there was a library of the Samanids in Bukhara, and a society of scientists (academy) in Khorezm. There were hospitals and pharmacies in large cities. The peoples of Central Asia in the early Middle Ages nominated many scientists (historians, mathematicians, geographers, botanists, astronomers) and art, whose work was an important contribution to the development of world culture.

Among the scientists of Central Asia of that time, doctors occupied a prominent place, who played an important role in the development of medicine.

In the countries of the East, in particular in Central Asia, there were numerous hospitals in the 9th-11th centuries. Experienced doctors worked in Bukhara, Khorezm, Merv and other cities of Central Asia in those years. Medicine was a natural manifestation of the high culture of the peoples of Central Asia.

A thousand years ago, a brilliant man named Abu Ali Hussein ibn-Abdallah ibn-Ali ibn-Sina lived in Bukhara. Ibn Sina was an encyclopedic scientist. His scientific heritage is very extensive and covers all branches of knowledge of that time: philosophy, logic, music, poetics, linguistics, medicine, mathematics, astronomy, chemistry, biology, geology, and others.

A little over a hundred years after his death, by order of religious fanatics in Baghdad, Ibn Sina's philosophical books will be burned on the main square, and a few hundred years after the invention of the printing press, immediately after the Bible, five huge volumes of the Canon of Medicine will be printed. Abu Ali al Hussein ibn-Abdallah ibn-Sina was born in September 960 in the small village of Afshan near Bukhara. In his biography, Ibn Sina wrote: "My father was from Balkh and came from there to Bukhara during the reign of the Samanid Nukh ibn Mansur and took up work there in the divan - office....

The Canon of Medicine is one of the most famous books in the history of medicine. In essence, this is a 
CURRENT RESEARCH JOURNAL OF PHILOLOGICAL SCIENCES 2(12):

52-55, December 2021

DOI: https://doi.org/10.37547/philological-crjps-02-12-11

ISSN 2767-3758

(C2021 Master Journals

Crossref do

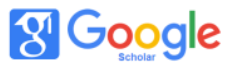

Accepted06 ${ }^{\text {th }}$ December, 2021 \& Published $11^{\text {th }}$ December, 2021

whole medical encyclopedia, considering with great completeness (within the knowledge of that time) everything that relates to human health and diseases.

This major work, which includes about 200 printed sheets, was translated from Arabic into Latin in the twelfth century and was sold in many manuscripts. When the printing press was invented, Canon was among the first printed books, and rivaled the Bible in the number of editions. The Latin text of the Canon of Medicine was first published in 1473, and the Arabic text in 1543. The exact date of completion of work on "Canon" has not been set. Presumably this is 1020. The Canon of Medicine is an extensive work of 5 books.

Book 1 is about theoretical medicine. The book is divided into four parts. The first part defines medicine, the second deals with diseases, the third deals with maintaining health, and the fourth deals with methods of treatment.

Book 2 describes "simple" medicines, Ibn Sina's teaching about medicines, their nature, and their testing is described. 811 products of plant, animal and mineral origin are listed alphabetically, indicating their action, methods of application, rules for collection and storage.

Book 4 is devoted to surgery, the treatment of dislocations and fractures, the general doctrine of fever (crises of illness). It talks about tumors, purulent inflammation of the subcutaneous tissue, as well as infectious diseases. The main issues of the doctrine of poisons are highlighted.

\section{Conclusion}

Book 5 contains a description of "complex" drugs, as well as poisons and antidotes.

Pharmacy and pharmacology is an attempt to combine the collected numerous materials into a system, to link them with clinical observations. The drugs recommended in the "Canons of Medicine" are varied, many of them later entered into scientific pharmacology.

Systematicity and consistency as great advantages of the "Canon" were noted even by those who were inclined to underestimate the importance of Ibn Sina in the history of medicine. The success of the "Canon of Medicine" was due to the clarity, persuasiveness, simplicity of describing the clinical picture of diseases, the accuracy of therapeutic and dietary prescriptions. These features quickly created huge popularity for "Canon", and its author was provided with "autocratic power for five centuries throughout the medical world of the Middle Ages."

\section{REFERENCES}

1. Azizovna, A. Z. (2021). CULTURE OF TURKESTAN IN THE SECOND HALF OF THE 19 CENTURY. Berlin Studies Transnational Journal of Science and Humanities, 1(1.5 Pedagogical sciences).

2. Чориева, М. А. (2020). Экономика и денежное обращение (монеты) в Бухарском эмирате при мангытах (на рубеже 19-20 веков). Наука, техника и образование, (5 (69)), 53-56.

3. Azizovna, A. Z. (2020). Religious and Mystic Views of Ahmad Donish. Electronic Research Journal of Social Sciences and Humanities, 2, 273-276.

4. Ахмедова, 3. А., \& Чориева, М. А. (2020). ТРУД АХМАДА ДОНИША «ИСТОРИЯ МАНГИТСКИХ ГОСУДАРЕЙ» КАК ЦЕННЫЙ ИСТОЧНИК ПО ИСТОРИИ БУХАРСКОГО ХАНСТВА ВТОРОЙ ПОЛОВИНЫ ХVIIIПЕРВОЙ ПОЛОВИНЫ XIX ВВ. Наука, техника и образование, (11 (75)). 
CURRENT RESEARCH JOURNAL OF PHILOLOGICAL SCIENCES 2(12):

52-55, December 2021

DOI: https://doi.org/10.37547/philological-crjps-02-12-11

ISSN 2767-3758

(C)2021 Master Journals

crossref do) 8: Google

Accepted06 ${ }^{\text {th }}$ December, 2021 \& Published $11^{\text {th }}$ December, 2021

5. Чориева, М. А. (2020). СОЦИАЛЬНОЭКОНОМИЧЕСКОЕ, ПОЛИТИЧЕСКОЕ ПОЛОЖЕНИЕ БУХАРСКОГО ЭМИРАТА В КОНЦЕ XIX ВЕКА. Наука, техника и образование, (11 (75)).

6. Azizovna, A. Z. (2021). THE ROLE OF TEACHING PHILOSOPHY IN MEDICAL UNIVERSITY. Наука, техника и образование, (6 (81)), 44-48.

7. Ахмедова, 3. А. (2018). Астрономические взгляды Ахмада Дониш. Вестник науки и образования, (11 (47)).

8. Ахмедова, 3. А. (2020). HUMAN BEING IN THE WORKS OF MEDIEVAL THINKERS. Новый день в медицине, (4), 115-118.

9. Ахмедова, 3. А. (2021). ХІХ АСРНИНГ ИККИНЧИ ЯРМИДА ТУРКИСТОН ЎЛКАСИ МАДАНИЯТИ. ВЗГЛЯД В ПРОШЛОЕ, 4(7).

10. Сагикызы, А., Шуршитбай, М., \& Ахмедова, 3. (2021). UPBRINGING AND EDUCATION AS FACTORS OF HUMAN CAPITAL DEVELOPMENT. Адам әлемі, 88(2), 18-25.

11. Ахмедова, 3. А., \& Турсунов, К. С. (2020). Интеграционный процесс в рамках Европейского союза. Наука, техника и образование, (5 (69)), 49-52. 